\title{
Large- and Small-Scale Environmental Factors Drive Distributions of Ant Mound Size Across a Latitudinal Gradient
}

\author{
Orsolya Juhász ${ }^{1,2, *(1)}$, Zoltán Bátori ${ }^{1}$, Gema Trigos-Peral ${ }^{3}$, Gábor Lőrinczi ${ }^{1}$, Gábor Módra ${ }^{1,4}$, \\ Imola Bóni ${ }^{1}$, Péter János Kiss ${ }^{1,4}$, Dianne Joy Aguilon ${ }^{1,4,5}{ }^{(D}$, Anna Tenyér 6 and István Maák ${ }^{1,3}$ \\ 1 Department of Ecology, University of Szeged, Közép fasor 52, H-6726 Szeged, Hungary; \\ zbatory@gmail.com (Z.B.); lorinczig@gmail.com (G.L.); modragabi@gmail.com (G.M.); \\ imolaboni@gmail.com (I.B.); kisspeterjanos003@gmail.com (P.J.K.); ddaguilon@up.edu.ph (D.J.A.); \\ bikmakk@gmail.com (I.M.) \\ 2 Doctoral School in Biology, Faculty of Science and Informatics, University of Szeged, Közép fasor 52, \\ H-6726 Szeged, Hungary \\ 3 Museum and Institute of Zoology, Polish Academy of Sciences, Wilcza Street 64, 00-679 Warsaw, Poland; \\ getriral@googlemail.com \\ 4 Doctoral School of Environmental Sciences, University of Szeged, Rerrich Béla Square 1, \\ H-6720 Szeged, Hungary \\ 5 Department of Forest Biological Sciences, College of Forestry and Natural Resources, \\ University of the Philippines Los Baños, Laguna 4031, Philippines \\ 6 Department of Physical Geography and Geoinformatics, University of Szeged, Egyetem Street 2-6, \\ H-6722 Szeged, Hungary; a2na9211@gmail.com \\ * Correspondence: juhasz.orsolya.4@stud.u-szeged.hu
}

Received: 11 May 2020; Accepted: 1 June 2020; Published: 4 June 2020

\begin{abstract}
Red wood ants are keystone species of forest ecosystems in Europe. Environmental factors and habitat characteristics affect the size of their nest mounds, an important trait being in concordance with a colony's well-being and impact on its surroundings. In this study, we investigated the effect of large-scale (latitude and altitude) and small-scale environmental factors (e.g., characteristics of the forest) on the size of nest mounds of Formica polyctena in Central Europe. We predicted that the change in nest size is in accordance with Bergmann's rule that states that the body size of endotherm animals increases with the higher latitude and/or altitude. We found that the size of nests increased along the latitudinal gradient in accordance with Bergmann's rule. The irradiation was the most important factor responsible for the changes in nest size, but temperature and local factors, like the perimeter of the trees and their distance from the nest, were also involved. Considering our results, we can better understand the long-term effects and consequences of the fast-changing environmental factors on this ecologically important group. This knowledge can contribute to the planning of forest management tactics in concordance with the assurance of the long-term survival of red wood ants.
\end{abstract}

Keywords: altitudinal gradient; Bergmann's rule; Formica polyctena; latitudinal gradient; nest mound

\section{Introduction}

The distribution of species is determined by different environmental gradients, which change along with latitude and altitude [1]. The most important environmental factors having gradients across the globe are temperature, precipitation, and irradiation [1,2]. It is well known that temperature generally decreases and precipitation generally increases linearly with altitude [2], while irradiation decreases with increasing latitude [3]. Ecologists have long-recognised the role of these environmental gradients as ideal laboratories along which to study changes in functional, life-history, and structural characteristics 
of species [4-11]. As a result, many types of "ecological" rules have been proposed and used by researchers. For instance, according to the well-known ecogeographic pattern (i.e., "Bergmann's rule"), the body size of endothermic vertebrates increases with decreasing temperature [4].

Bergmann's rule was firstly applied to a species within a genus [4]. Since then, the relationships between body size, latitude, and altitude have been investigated for several taxa. As a result, studies on endotherms [5,12-14] and ectotherms [15-18] have supported or challenged the validity of Bergmann's rule [8]. The original explanation behind Bergmann's rule was related to the heat conservation mechanism, hypothesising that animals with a larger body size can conserve more heat because of their higher surface area to volume ratio [8]. Contrary to endotherms, ectotherms cannot maintain a stable body temperature, therefore, the validity of Bergmann's rule is questionable in their case. This is the main reason why other hypotheses have also been proposed to explain the above relationships, such as the "starvation resistance hypothesis" and the "resource availability hypothesis" [8]. According to the starvation resistance hypothesis, the individuals with a larger body size (and therefore higher amount of reserves) can endure better the unfavourable periods with low food availability [8]. In sphingid moths, however, the body size shows a latitudinal cline, supporting the resource availability hypothesis [18] that states that the availability of resources (e.g., in time or depending on competition) affects body size, which will increase in areas where resources are available for a longer time and/or the competition is lower [8]. Nonetheless, many ectotherm species follow the Bergmann's rule, such as Scathophaga stercoraria (Diptera), Psammodromus algirus (Lacertidae), many bee genera (like Andrena or Halictus), and Bufo minshanicus (Bufonidae) [16,19-21]. Here, we focus on the changes in the nest size patterns of ants with altitude and latitude in Europe.

According to the superorganism hypotheses, ants can build complex nesting structures that are equivalent to the endotherm organism's body $[6,22,23]$, and ant workers within these structures can actively regulate the temperature [6,24-28]. Moreover, the size of the nesting structures is in close relation to the colony size (i.e., the increase in any of the three defining parameters of the nest volume will result in a higher number of inhabiting workers) [29], so both the colony size and the size of individual colony members (workers) can be the target of Bergmann's rule. Indeed, a few studies found that both colony and individual size can increase with increasing latitude [20,30-32], whereas altitudinal changes can also lead to alterations in the colony [33] and individual size [34,35]. However, the findings of these latitudinal and altitudinal studies are contradictory and species-specific.

Red wood ants from the Formica rufa group can have one of the largest nest structures found in the northern hemisphere [36,37] that correlates with the colony size and is a good indicator of the colony's well-being [26,38-42]. However, information is scarce about the effects of the latitudinal and altitudinal gradients on these species' nest sizes that can be related to large- and small-scale environmental factors [41]. Large-scale environmental factors are mostly weather components such as temperature, irradiation, or precipitation that can influence the nest size in many ways. For instance, the daily temperature variance of Formica nests decreases with rising latitude [43], but the respiration rate increases with rising altitude [44]. Small-scale environmental factors are mostly related to habitat characteristics, such as the age and distance of the trees around the nests that can influence the size of nests [45-47] and can mediate the effects of large-scale environmental factors. For example, Formica polyctena builds larger nests in shady forest interiors, whereas F. rufa builds smaller nests in well-lit forest edges [36].

According to our knowledge, a comprehensive analysis of large- and small-scale environmental factors affecting the nest size of red wood ants was not in the focus of any study and only a few studies investigated the effects of large-scale environmental gradients on ants within Europe, and among them, the Western European region is over represented [31,32,48]. Red wood ants from the Formica rufa group are ideal targets for such a study, as species from this group, like Formica polyctena, build large, easily recognisable above-ground nest structures that can be $1.5-3 \mathrm{~m}$ wide and up to $2.5 \mathrm{~m}$ in height [36]. This complex structure, situated mostly on equatorial-facing slopes (where solar exposure and the incoming solar radiation is higher than in polar-facing slopes) [35], is meant to ensure the thermal 
stability of the colony and adequate warmth for the larval development in the spring period [37]. Consequently, solar irradiation and temperature can have important effects on the nest size of red wood ants [36,37,49-51].

In this study, we investigated the effects of latitude, altitude (large-scale environmental factors), and forest conditions (small-scale environmental factors) on the nest size of Formica polyctena along a south to north transect in Central Europe (Figure 1). We hypothesised that large-scale environmental factors (temperature, precipitation, and irradiation) cause changes in nest size along the gradients and that these changes are in accordance with Bergmann's rule. Moreover, we also investigated the effects of the small-scale environmental factors (the distance and perimeter of the nearest trees around the nests) that can play an important role in nest size variability. We hypothesised that growing shade (closer, bigger trees) will cause an increase in nest size.

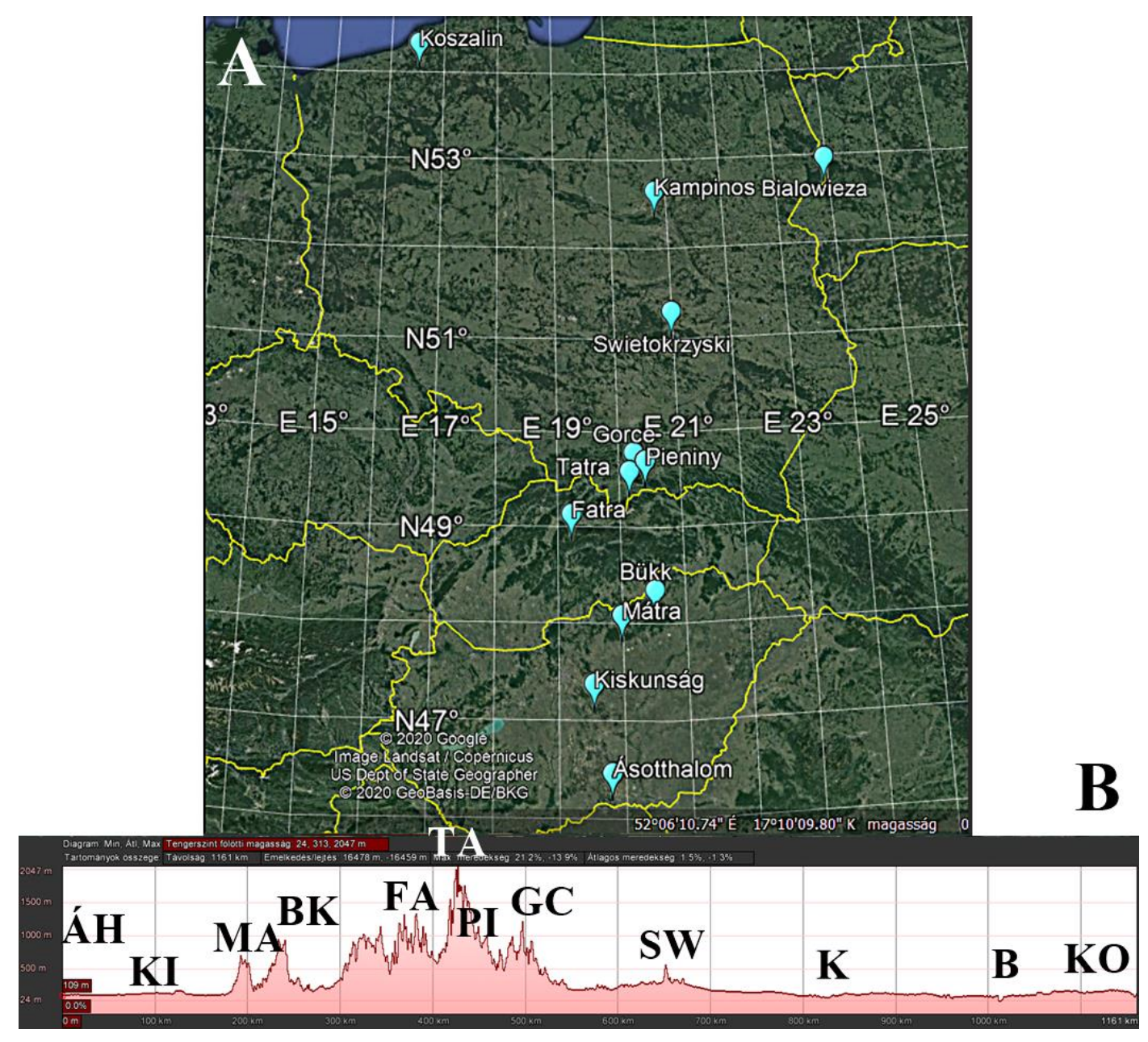

Figure 1. Study regions along the latitudinal (A) and altitudinal (B) gradient in Central Europe (Hungary, Slovakia, and Poland). Abbreviations: Hungarian lowland: ÁH = Ásotthalom, KI = Kiskunság; Southern Carpathian foothill: $\mathrm{MA}=$ Mátra; higher Carpathians (mountain range): $\mathrm{BK}=$ Bükk, FA = Fatra, TA = Tatra, PI = Pieniny; Northern Carpathian foothill: GC = Gorce; Polish lowland: SW = Świętokrzyska, $\mathrm{K}=$ Kampinos, $\mathrm{B}=$ Białowieza, $\mathrm{KO}=$ Koszalin.

\section{Materials and Methods}

\subsection{Study Sites}

The study was conducted during the summer months (from the second half of June to the first half of August) of 2017-2019. We sampled the nests of Formica polyctena along a $900 \mathrm{~km}$ transect (study 
area hereafter) passing through three Central European countries (Hungary, Slovakia, and Poland). The transect contained a latitudinal $\left(46.215283^{\circ} \mathrm{N}-54.069650^{\circ} \mathrm{N}\right)$ and an altitudinal gradient $(75-954$ m; Figure 1; Table S1), along which comprised the 12 study regions (Figure 1; Table 1). In the Great Hungarian Plain (Hungarian lowland), we sampled two regions (Ásotthalom and Kiskunság), while in the much bigger Polish lowland, we sampled four regions (from the middle of Poland to the Baltic Sea: Świętokrzyska, Kampinos, Białowieza, and Koszalin). To cover the altitudinal gradient between the Hungarian and Polish lowlands, we sampled the foothills of the Carpathians (Mátra Mountains in Hungary and Gorce Mountains in Poland). The study regions in the Carpathians were the Bükk, Fatra, Tatra, and Pieniny Mountains. We chose the number of regions to be representative of the size of the study area, whereas the distance value of the sampling sites is in compliance with their distance from each other (see Statistical analyses).

Table 1. Distance weighted numbers, coordinates, and average altitude of the sampling areas across Central Europe (Hungary, Slovakia, and Poland).

\begin{tabular}{ccccc}
\hline Sampling Site & Distance Value & Latitude (N) & Longitude (E) & Average Altitude (m) \\
\hline Ásotthalom & 1 & $46.215283^{\circ}$ & $19.782783^{\circ}$ & 118 \\
Kiskunság & 6 & $47.121150^{\circ}$ & $19.504833^{\circ}$ & 122 \\
Mátra & 10 & $47.827283^{\circ}$ & $19.974950^{\circ}$ & 429 \\
Bükk & 13 & $48.081000^{\circ}$ & $20.502667^{\circ}$ & 789 \\
Fatra & 20 & $48.882450^{\circ}$ & $19.211333^{\circ}$ & 871 \\
Tatra & 24 & $49.325650^{\circ}$ & $20.153967^{\circ}$ & 787 \\
Pieniny & 25 & $49.435850^{\circ}$ & $20.423150^{\circ}$ & 602 \\
Gorce & 26 & $49.520267^{\circ}$ & $20.232833^{\circ}$ & 724 \\
Świętokrzyska & 35 & $50.886933^{\circ}$ & $21.094567^{\circ}$ & 302 \\
Kampinos & 43 & $52.361400^{\circ}$ & $20.792717^{\circ}$ & 88 \\
Białowieza & 45 & $52.698183^{\circ}$ & $23.891283^{\circ}$ & 178 \\
Koszalin & 61 & $54.069650^{\circ}$ & $16.535000^{\circ}$ & 90 \\
\hline
\end{tabular}

\subsection{Sampling Design}

In each study region, we sampled the ant nests within $150 \times 150$ m quadrates ("sampling sites" hereafter), which can be considered a good representation of the territory of Formica polyctena [39]. We used GPS (GARMIN Oregon $700 \mathrm{t}$ ) to mark the location of nests within the sampling sites. The altitude and latitude of the sampling sites were determined with the help of Google Earth (Google 2019). The sampling sites were managed mixed forests of deciduous and coniferous trees, with coniferous species such as Picea abies, Pinus sylvestris, P. nigra, Abies alba, and Larix decidua. The most common non-coniferous trees were Betula pendula, Robinia pseudoacacia, and Quercus spp. The age of these forests (based on local forestry databases: NÉBIH, Mapový portal KIMS, Bank Danych o Lasach) was on average 65 years (between 30.75 and 116). The number of sampling sites per region depended on the available Formica polyctena populations. In most regions (Ásotthalom, Kiskunság, Bükk, Fátra, Pieniny, Świętokrzyska, Kampinos, Białowieza), we could sample three sites, while in Gorce, Tatra, and Mátra Mountains, we found only two populations, and in Koszalin, only one population. The temperature, precipitation and irradiation data for the regions were obtained from the WorldClim (resolution 30 arc-second, period 1950-2000, Table S1) database [52]. We used whole-year environmental data because despite that red wood ants hibernate during winter, the environmental factors (e.g., temperature) in this period affect early spring survival rates (e.g., raising winter/hibernating temperatures cause elevated death rates in colonies) [42]. The average temperature changed between 10.69 and $4.86^{\circ} \mathrm{C}$ from the lowest elevation to the highest, whereas the average irradiation was between

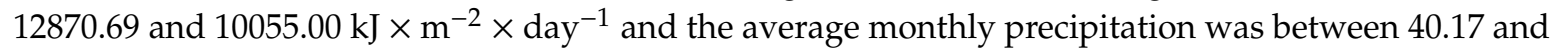
$99.5 \mathrm{~mm}$ along the transect from south to north (Table S1). 
Within each sampling site, we measured the size of each nest (two perpendicular diameters and height). The above-ground nest volume (i.e., semi-ellipsoid) was determined using the following equation:

$$
V=\frac{0.75 * \pi * r_{1} * r_{2} * h}{2}
$$

where $h$ is the height of the nest, and $r_{1}$ and $r_{2}$ are the two perpendicular nest radii. We used this equation because the above-ground nest volume is closely related to the red wood ant colony size [29,53]. To describe the small-scale habitat characteristics, we also measured the distance of all the closest trees in a circle surrounding the nests relevant to their shading (with laser telemeter SNDWAY SW-T80, accuracy: $\pm 2 \mathrm{~mm}$ ) and the trunk perimeter of these trees at $1.3 \mathrm{~m}$ height, and we also identified the trees at the species level within each sampling site.

\subsection{Statistical Analyses}

We used linear mixed-effects models (LMM, Gaussian error, maximum likelihood fit) to analyse the effect of the latitude, altitude, and forest age on the mean nest size of F. polyctena along the transect. In the model, the latitude, altitude, and forest age were included as explanatory variables. The latitude was included as an increasing "Distance value" starting from the southernmost sampling site (Ásotthalom) and added +1 value with every $20 \mathrm{~km}$ (in beeline) passing to north (Table 1 ). The correlation of the background variables (Distance of trees, Perimeter of trees, Temperature, Precipitation, Irradiation) with the latitude (Distance value) was tested with Pearson's product moment correlation.

We applied a principal component analysis (PCA) on the background variables to test for possible correlations among the large-scale (Temperature, Precipitation, Irradiation) and small-scale environmental factors (Distance of trees, Perimeter of trees) throughout the sampling sites. The PCA was carried out on the covariance matrix based on the average value of the variables. The link between PCA scores (from the first three PCs) of the sampling sites and mean nest size was analysed using linear mixed-effect models (LMMs). The full model included the mean nest size as dependent variables, the PCA scores of the sampling sites for first three PCs as explanatory variables, and the ID of the sampling sites as a random factor.

The effect of the three groups revealed by the PCA (1: Hungarian lowland regions and the Southern Carpathian foothill (Mátra), 2: Mountainous regions and foothills and the Northern Carpathian foothill (Gorce), 3: Polish lowland regions; see also Results) on the mean nest size in the sampling sites was tested with LMM (Gaussian error, maximum likelihood fit). In the model, the mean nest size was included as a dependent variable and group ID as an explanatory factor.

If necessary, the variables were log-transformed prior to the analyses to meet the normality and homogeneity of variances. In all models, the sampling site ID was included as a random factor. Statistical analyses were carried out in R Statistical Environment (R Core Team 2019). LMMs were performed using the lmer function from the lme4 package [54]. Automated model selection was performed with the help of the dredge function (MuMIn package) [55]. PCA analysis was performed using the prcomp function from the stats package. The emmeans function (emmeans package) was used for sequential post-hoc comparisons among factor levels when performing LMM analyses [56].

\section{Results}

Overall, we found 393 nests of F. polyctena in our study area. The average nest size for the whole study area was $359.96( \pm 249.1 \mathrm{SE}) \mathrm{dm}^{3}$. The smallest nest size was $0.02 \mathrm{dm}^{3}$ (Kampinos National Park, Poland), whereas the biggest was $3506.9 \mathrm{dm}^{3}$ (Mátra Mountains, Hungary). The smallest average nest size was 80.45 ( $\pm 54.07 \mathrm{SE}) \mathrm{dm}^{3}$ (Kiskunság, Hungary) and the biggest was $908.17( \pm 575.63 \mathrm{SE}) \mathrm{dm}^{3}$ (Białowieza, Poland).

In relation to increasing latitude, the temperature and irradiation decreased from south to north. On the other hand, in relation to increasing altitude, temperature decreased while precipitation increased (see Table S1). We found that increasing latitude caused a significant increase in nest 
size (LMM $t=2.18, p=0.03)$, whereas the altitude and the age of forests did not $(t<0.77, N S)$. We also examined which background variables changed along the latitude, and we found a significant negative correlation with irradiation (Pears. $r=-0.88, t=-10.28, p<0.001$ ) and with temperature (Pears. $r=-0.41, t=-2.42, p<0.05)$. However, precipitation, the distance of trees from the nest, and the tree perimeter did not correlate with latitude (Pears. $r<0.3, t<1.72, N S$ ).

The PCA analysis of the background variables (Distance of trees, Perimeter of trees, Temperature, Precipitation, Irradiation) revealed that the first axis explains $48.25 \%$, the second $29.37 \%$, and the third $13.15 \%$ of the variance in the data (Figure 2; Table 2). The scores of the sampling sites taken according to the first three axes showed that those belonging to PC2 have a significant effect on nest size $(t=-3.26$, $p<0.01$; Table 2).

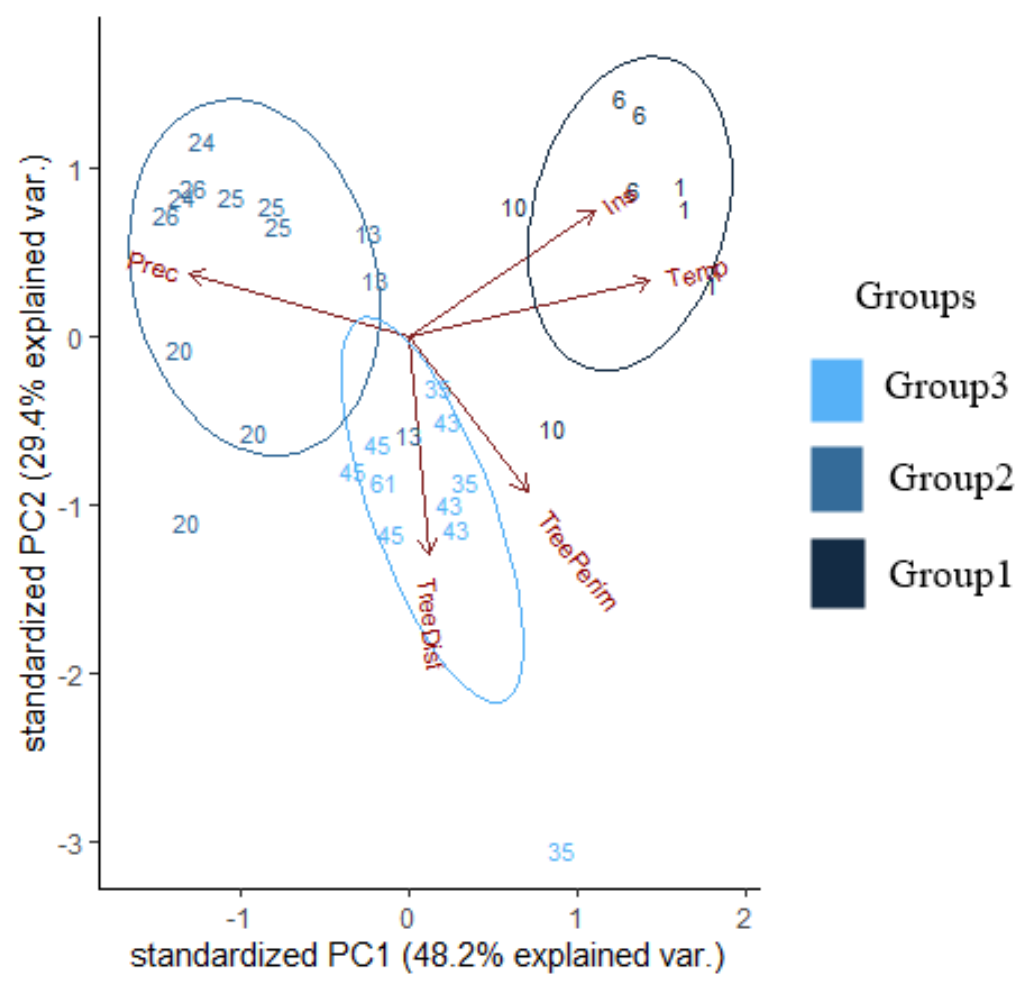

Figure 2. Visual representation of the principal component analyses (PCA) and the three groups (Group1 = Hungarian lowland regions, including the Southern Carpathian foothill (Mátra); Group2 = higher Carpathian Mountainous regions, including the Northern Carpathian foothill (Gorce); Group3 = Polish lowland regions) based on the background variables. Prec $=$ average yearly precipitation, Ins = average yearly irradiation, Temp = average yearly temperature, TreeDist = distance of the closest trees, TreePerim $=$ perimeter of the closest trees.

Table 2. The shared percentages of the background variables on the first three PCA axes.

\begin{tabular}{cccc}
\hline Background Variables & PC1 & PC2 & PC3 \\
\hline Distance of trees & $5.2 \%$ & $-71 \%$ & $54.87 \%$ \\
Perimeter of trees & $30.11 \%$ & $-50.69 \%$ & $-76.3 \%$ \\
Temperature & $61.24 \%$ & $19.9 \%$ & $-6.58 \%$ \\
Precipitation & $-55.56 \%$ & $20.2 \%$ & $-28.44 \%$ \\
Irradiation & $47.19 \%$ & $40.72 \%$ & $17.69 \%$ \\
\hline
\end{tabular}

The PCA analyses also revealed three groups (Figure 2): Group1 clustered the sampling sites from the Hungarian lowland regions (Ásotthalom and Kiskunság), Group2 from the mountainous regions (Mátra, Bükk, Fatra, Tatra, Pieniny, and Gorce Mountains), and Group3 from the Polish lowland regions (Świętokrzyska, Kampinos, Białowieza, and Koszalin; Figure 2). We found that the average nest size in 
Group1 is significantly lower than in Group3 (LMM $t=-2.3, p=0.02)$. Group2 did not differ from either of the former two (LMM $-1.05<t<1.43, N S)$.

\section{Discussions}

According to our knowledge, this is the first study about the effects of large- and small-scale environmental factors on the nest size distribution of an ant species. We showed that the nest size of $F$. polyctena increased in Central Europe along a latitudinal gradient with decreasing irradiation and temperature in accordance with Bergmann's rule. On the other hand, the altitude did not have a significant effect despite the changes in temperature and precipitation along this gradient. Small-scale environmental factors (e.g., tree characteristics around the nests) also played a significant role in the variability of the nest size, mostly in the northern regions. As we expected, more shade (e.g., denser and bigger trees in the nest surroundings) caused an increase in the size of the nests.

Bergmann's rule predicts that body size increases in relation to decreasing temperature [4], and if we consider the colony of eusocial insects as a superorganism, where the nest structure can be the equivalent of the body $[6,22,23]$, we could apply the Bergmann's rule by measuring the changes in the size of the nests in relation to latitude or altitude. In red wood ants, not the temperature but rather irradiation seems to have a more pronounced effect on their biology. The lack of the effect of altitude strengthens this finding, as the temperature was the lowest in the mountainous regions. However, irradiation did not decrease significantly towards high elevation. If temperature would be the strongest factor affecting the nest size of red wood ants, we would have experienced an increase in nest size not only with increasing latitude but also with increasing altitude. Moreover, the increases in nest size are in concordance with other findings in ants that explain the larger colony size in the northern regions with the shorter growing seasons than in the temperate latitudes that kill smaller colonies through overwintering starvation [30].

The adequate temperature of nest structures built by red wood ants (e.g., F. polyctena) in early spring is achieved by the combined effect of several mechanisms [37]. The nests are usually located in places with high insolation (e.g., equatorial-facing slopes) [36,49], where workers can be often seen sunbathing on the surface of their nest collecting heat from the incoming solar radiation, and the metabolic heat production of the workers helps them to heat up the nests when the temperatures are still low and the snow has not been melted yet [37]. This also emphasises the importance of irradiation over temperature in obtaining earlier the adequate nest warmth. However, the original explanatory mechanism behind Bergmann's rule may be also valid [8], as the heat conservation of a colony can be better when its surface area to volume ratio is bigger. Consequently, larger colonies can heat up more efficiently their nests (with sunbathing and/or metabolic heat). Besides, the dome shape of the nests (acting like a sun-collector) also helps them to accumulate the incoming solar radiation, and together with the former characteristics, it allows their persistence in areas where irradiation is lower $[24,36,37]$. Indeed, in our case, irradiation decreased along increasing latitude, leading to an increase in average size towards the northern regions (Polish lowland). This is in line with other studies showing that irradiation (besides temperature) is a strong determinant of the nest occurrence of red wood ants [36,37,49-51].

The decreased irradiation values found in the Polish lowland regions not only resulted in larger mounds, but also granted higher importance to the small-scale environmental characteristics, such as the distance and perimeter of the nearby trees. In these sampling sites, irradiation is a limiting factor, so the shading (e.g., closer and bigger trees nearby the nests that can have a direct shading effect) and other microclimatic effects of the trees become more important, in contrast with southern regions where the higher amount of irradiation can compensate for the possible negative effects of the close-by trees. A similar correlation between the amount of irradiation and the distance from the closest trees surrounding the nests was observed also in other studies [51,57]. Overall, our study underpins the validity of the Bergmann's rule in a eusocial species and highlights the importance of large- and small-scale environmental factors that can affect the nest size distribution of these ants. 
Formica polyctena is one of the most dominant species in ant assemblages of boreal and temperate forest ecosystems, especially of mature coniferous Palaearctic forests (e.g., [58,59]). Moreover, red wood ants are important keystone species and ecosystem engineers [37], and the size of their nests can correlate with their long-time persistence and potential to fulfil their important ecological role [60]. Their presence affects the whole forest ecosystem through their various activities, influencing, among others, the soil composition, the nutrient cycles, and the presence of several other species, from plants to vertebrates $[37,61]$. Smaller nests, however, can provide a habitat for fewer myrmecophilous species [61], and their impact on forest ecosystems can be also negatively affected, lowering their importance in Central European coniferous and mixed-coniferous forests compared with northern European boreal forests. This knowledge leads to a better understanding of an ecologically important group like red wood ants, especially in the light of the anthropogenic climate change, which causes rising temperatures and sudden changes in weather. This might lead to a further decrease in the nest size of red wood ants [42], but also to the disappearance of their natural habitats [62,63]. Coniferous forests are continuously cut down to prevent bark beetle (Curculionidae: Scolytinae) infestation [63] and clear-cutting also has negative effects on the nest size and vitality of red wood ants $[38,42,64]$. Therefore, continuous large-scale monitoring of the changes in the nest sizes of red wood ants would be encouraged to be able to detect negative changes and to have time to develop and apply conservation strategies. Meanwhile, we encourage forestry managers to relocate red wood ant nests before clear-cutting to non-disturbed mixed coniferous-deciduous forest stands $[65,66]$. This, besides protecting the wood ants, through their potential role as biological protective agents, would also protect the forest where they will be relocated $[67,68]$.

\section{Conclusions}

This is the first study concerning the effects of large- and small-scale environmental factors on the nest size distribution of an ant species. Our research showed that the nest size of the red wood ant F. polyctena increases across a latitudinal gradient in Central Europe in accordance with Bergmann's rule. On the other hand, small-scale environmental factors (e.g., the characteristics of trees around the nests) also play a significant role in the variability of nest size, mostly in the northern regions. For example, more shading (e.g., denser, and bigger trees in the nest surroundings) caused an increase in the size of the nests.

Our findings may support forestry and conservation management because the continuous loss of coniferous forests due to bark beetle infestation (Curculionidae: Scolytinae) leads to habitat degradation in a short term. Relocation of the red wood ant nests would help to protect this environmentally important species group and the forest habitats they live in.

Supplementary Materials: The following are available online at http://www.mdpi.com/2075-4450/11/6/350/s1, Table S1: The yearly average temperature (Tavg), precipitation and irradiation of the sampling sites with the number of nests and the average nest sizes (NS), tree distances and perimeters around the nests across Central Europe (Hungary, Slovakia and Poland).

Author Contributions: O.J. and I.M. conceived and designed the experiments. O.J., G.T.-P., G.M., I.B., P.J.K., D.J.A., A.T. and I.M. performed the experiments. I.M. analysed the data. O.J. and I.M. wrote the manuscript. Z.B., G.T.-P. and G.L. provided editorial advice. All authors have read and agreed to the published version of the manuscript.

Funding: O.J. was supported by SZTE Open Access, grant number: 4724. I.E.M. was supported during the writing of the manuscript by a grant of the Polish National Science Center, Miniatura, project number 2017-01-X-NZ8-01042. Z.B. was supported by the NKFIH K 124796 grant.

Acknowledgments: The authors would like to thank the Forest Research Institute in Białowieża National Park, Gorce National Park, Tatra National Park and Museum and Institute of Zoology, Polish Academy of Sciences for their essential role in this research.

Conflicts of Interest: The authors declare no conflict of interest. The funders had no role in the design of the study; in the collection, analyses, or interpretation of data; in the writing of the manuscript, or in the decision to publish the results. 
Research Involving Human and Animal Participants: To obtain the data presented in the manuscript it has been necessary to involve animals, however, during the specimen collection the integrity of the colonies and nest structure were not harmed. This research does not involve human participants.

\section{References}

1. Folgarait, P.J. Ant biodiversity and its relationship to ecosystem functioning: A review. Biodivers. Conserv. 1998, 7, 1221-1244. [CrossRef]

2. Johnson, F.S.; Mo, T.; Green, A.E.S. Average latitudinal variation in ultraviolet radiation at the Earth's surface. Photochem. Photobiol. 1976, 23, 179-188. [CrossRef] [PubMed]

3. Tabony, R.C. The variation of surface temperature with altitude. Met. Mag. 1985, 114, 37-48.

4. Bergmann, K.G.L.C. Ueber die Verhaltnisse der Warmeokonomie der thiere zu ihrer grosse. Gottinger Studien 1847, 3, 595-708.

5. Geist, V. Bergmann's rule is invalid. Can. J. Zool. 1987, 65, 1035-1038. [CrossRef]

6. Hölldobler, B.; Wilson, E.O. The Ants; Harvard Univ. Press: Cambridge, MA, USA, 1990; pp. 23-33, 378-435.

7. Samson, D.A.; Rickart, E.A.; Gonzales, P.C. Ant diversity and abundance along an elevational gradient in the Philippines. Biotropica 1997, 29, 349-363. [CrossRef]

8. Blackburn, T.M.; Gaston, K.J.; Loder, N. Geographic gradients in body size: A clarification of Bergmann's rule. Divers. Distrib. 1999, 5, 165-174. [CrossRef]

9. Machac, A.; Janda, M.; Dunn, R.R.; Sanders, N.J. Elevational gradients in phylogenetic structure of ant communities reveal the interplay of biotic and abiotic constraints on diversity. Ecography 2011, 34, 364-371. [CrossRef]

10. Vandegehuchte, M.L.; Wermelinger, B.; Fraefel, M.; Baltensweiler, A.; Düggelind, C.; Brändli, U.-B.; Freitag, A.; Bernasconi, C.; Cherix, D.; Risch, A.C. Distribution and habitat requirements of red wood ants in Switzerland: Implications for conservation. Biol. Conserv. 2017, 212, 366-375. [CrossRef]

11. Economo, E.P.; Narula, N.; Friedman, N.R.; Weiser, M.D.; Guénard, B. Macroecology and macroevolution of the latitudinal diversity gradient in ants. Nat. Commun. 2018, 9, 1778. [CrossRef]

12. Alhajeri, B.H.; Steppan, S.J. Association between climate and body size in rodents: A phylogenetic test of Bergmann's rule. Mamm. Biol. 2016, 81, 219-225. [CrossRef]

13. Gohli, J.; Voje, K.L. An interspecific assessment of Bergmann's rule in 22 mammalian families. BMC Evol. Biol. 2016, 16, 222. [CrossRef] [PubMed]

14. Torres-Romero, E.J.; Morales-Castilla, I.; Olalla-Tárraga, M.Á. Bergmann's rule in the oceans? Temperature strongly correlates with global interspecific patterns of body size in marine mammals. Glob. Ecol. Biogeogr. 2016, 25, 1206-1215. [CrossRef]

15. Mousseau, T.A. Ectotherms follow the converse to Bergmann's rule. Evolution 1997, 51, 630-632. [CrossRef]

16. Blanckenhorn, W.U.; Demont, M. Bergmann and converse Bergmann latitudinal clines in arthropods: Two ends of a continuum? Integr. Comp. Biol. 2004, 44, 413-424. [CrossRef]

17. Feldman, A.; Meiri, S. Australian Snakes Do Not Follow Bergmann's Rule. Evol. Biol. 2014, 41, 327-335. [CrossRef]

18. Beerli, N.; Bärtschi, F.; Ballesteros-Mejia, L.; Kitching, I.J.; Beck, J. How has the environment shaped geographical patterns of insect body sizes? A test of hypotheses using sphingid moths. J. Biogeogr. 2019, 46, 1687-1698. [CrossRef]

19. Zamora-Camacho, F.J.; Reguera, S.; Moreno-Rueda, G. Bergmann's Rule rules body size in an ectotherm: Heat conservation in a lizard along a 2200-metre elevational gradient. J. Evol. Biol. 2014, 27, 2820-2828. [CrossRef]

20. Gérard, M.; Vanderplanck, M.; Franzen, M.; Kuhlmann, M.; Potts, S.G.; Rasmont, P.; Schweiger, O.; Michez, D. Patterns of size variation in bees at a continental scale: Does Bergmann's rule apply? Oikos 2018, 127, 1095-1103. [CrossRef]

21. Yu, T.L.; Wang, D.L.; Busam, M.; Deng, Y.H. Altitudinal variation in body size in Bufo minshanicus supports Bergmann's rule. Evol. Ecol. 2019, 33, 449-460. [CrossRef]

22. Wheeler, W.M. The ant-colony as an organism. J. Morphol. 1911, 22, 307-325. [CrossRef]

23. Wilson, E.O.; Hölldobler, B. The Superorganism: The Beauty, Elegance, and Strangeness of Insect Societies; W. W. Norton \& Company: New York, NY, USA, 2008; pp. 3-10. 
24. Kadochová, Š.; Frouz, J. Red wood ants Formica polyctena switch off active thermoregulation of the nest in autumn. Insect. Soc. 2014, 61, 297-306. [CrossRef]

25. Kadochová, Š.; Frouz, J. Thermoregulation strategies in ants in comparison to other social insects, with a focus on red wood ants (Formica rufa group). F1000Research 2014, 2, 280. [CrossRef] [PubMed]

26. Czechowski, W.; Radchenko, A.; Czechowska, W. The Ants (Hymenoptera, Formicidae) of Poland; Museum and Institute of Zoology PAS: Warsaw, Poland, 2002; pp. 71-80.

27. Stabentheiner, A.; Pressl, J.; Papst, T.; Hrassnigg, N.; Crailsheim, K. Endothermic heat production in honeybee winter clusters. J. Exp. Biol. 2003, 206, 353-358. [CrossRef] [PubMed]

28. Hozumi, S.; Mateus, S.; Kudô, K.; Kuwahara, T.; Yamane, S.; Zucchi, R. Nest thermoregulation in Polybia scutellaris (White) (Hymenoptera: Vespidae). Neotrop. Entomol. 2010, 39, 826-828. [CrossRef]

29. Punttila, P.; Kilpeläinen, J. Distribution of mound-building ant species (Formica spp., Hymenoptera) in Finland: Preliminary results of a national survey. Ann. Zool. Fenn. 2009, 46, 1-15. [CrossRef]

30. Kaspari, M.; Vargo, E.L. Colony size as a buffer against seasonality: Bergmann's rule in social insects. Am. Nat. 1995, 145, 610-632. [CrossRef]

31. Cushman, J.H.; Lawton, J.H.; Manly, B.F.J. Latitudinal patterns in European ant assemblages: Variation in species richness and body size. Oecologia 1993, 95, 30-37. [CrossRef]

32. Heinze, J.; Foitzik, S.; Fischer, B.; Wanke, T.; Kipyatkov, V.E. The significance of latitudinal variation in body size in a holarctic ant, Leptothorax acervorum. Ecography 2003, 26, 349-355. [CrossRef]

33. Geraghty, M.J.; Dunn, R.R.; Sanders, N.J. Body size, colony size, and range size in ants (Hymenoptera: Formicidae): Are patterns along elevational and latitudinal gradients consistent with Bergmann's Rule? Myrmecol. News 2007, 10, 51-58.

34. Bernadou, A.; Römermann, C.; Gratiashvili, N.; Heinze, J. Body size but not colony size increases with altitude in the holarctic ant, Leptothorax acervorum. Ecol. Entomol. 2016, 41, 733-736. [CrossRef]

35. Purcell, J.; Pirogan, D.; Avril, A.; Bouyarden, F.; Chapuisat, M. Environmental influence on the phenotype of ant workers revealed by common garden experiment. Behav. Ecol. Sociobiol. 2016, 70, 357-367. [CrossRef]

36. Seifert, B. The Ants of Central and North Europe; Lutra Verlags-und Vertiebsgesellschaft: Tauer, Germany, 2018; pp. 299-332.

37. Stockan, J.A.; Robinson, E.J. Wood Ant Ecology and Conservation; Cambridge Univ. Press: Cambridge, UK, 2016.

38. Sorvari, J.; Hakkarainen, H. Deforestation reduces nest mound size and decreases the production of sexual offspring in the wood ant Formica aquilonia. Ann. Zool. Fenn. 2005, 42, 259-267.

39. Sorvari, J.; Hakkarainen, H. Forest clear-cutting causes small workers in the polydomous wood ant Formica aquilonia. Ann. Zool. Fenn. 2009, 46, 431-438. [CrossRef]

40. Chen, J.-H.; Robinson, E.J.H. The relationship between canopy cover and colony size of the wood ant Formica lugubris-implications for the thermal effects on a keystone ant species. PLoS ONE 2014, 9. [CrossRef]

41. Chen, J.; Franklin, J.F.; Spies, T.A. Growing-season microclimatic gradients from clearcut edges into old-growth Douglas-fir forests. Ecol. Appl. 1995, 5, 74-86. [CrossRef]

42. Sorvari, J.; Haatanen, M.-K.; Vesterlund, S.-R. Combined effects of overwintering temperature and habitat degradation on the survival of boreal wood ant. J. Insect Conserv. 2011, 15, 727-731. [CrossRef]

43. Frouz, J.; Finer, L. Diurnal and seasonal fluctuations in wood ant (Formica polyctena) nest temperature in two geographically distant populations along a south-north gradient. Insect. Soc. 2007, 54, 251-259. [CrossRef]

44. Jílková, V.; Cajthaml, T.; Frouz, J. Respiration in wood ant (Formica aquilonia) nests as affected by altitudinal and seasonal changes in temperature. Soil Biol. Biochem. 2015, 86, 50-57. [CrossRef]

45. Punttila, P.; Haila, Y.; Pajunen, T.; Tukia, H. Colonization of clear-cut forests by ants in the Southern Finnish taiga: A quantitative survey. Oikos 1991, 61, 250-262. [CrossRef]

46. Maeto, K.; Sato, S. Impacts of forestry on ant species richness and composition in warm-temperate forests of Japan. For. Ecol. Manag. 2004, 187, 213-223. [CrossRef]

47. Procter, D.S.; Cottrell, J.; Watts, K.; Robinson, E.J.H. Do non-native conifer plantations provide benefits for a native forest specialist, the wood ant Formica lugubris? For. Ecol. Manag. 2015, 357, 22-32. [CrossRef]

48. Arnan, X.; Cerdá, X.; Retana, J. Relationships among taxonomic, functional, and phylogenetic ant diversity across the biogeographic regions of Europe. Ecography 2017, 40, 448-457. [CrossRef]

49. Jones, J.C.; Oldroyd, B.P. Nest thermoregulation in social insects. Adv. Insect Physiol. 2007, 33, $153-191$. 
50. Kilpeläinen, J.; Punttila, P.; Finér, L.; Niemelä, P.; Domisch, T.; Jurgensen, M.F.; Neuvonen, S.; Ohashi, M.; Risch, A.C.; Sundström, L. Distribution of ant species and mounds (Formica) in different-aged managed spruce stands in Eastern Finland. J. Appl. Entomol. 2008, 132, 315-325. [CrossRef]

51. Sondej, I.; Domisch, T.; Finér, L.; Czechowski, W. Wood ants in the Bialowieza Forest and factors affecting their distribution. Ann. Zool. Fenn. 2018, 55, 103-114. [CrossRef]

52. Hijmans, E.J.; Cameron, S.E.; Parra, J.L.; Jones, P.G.; Jarvis, A. Very high resolution interpolated climate surfaces for global land areas. Int. J. Climatol. 2005, 25, 1965-1978. [CrossRef]

53. Risch, A.C.; Jurgensen, M.F.; Schütz, M.; Page-Dumroese, D.S. The Contribution of Red Wood Ants to Soil C and $\mathrm{N}$ Pools and $\mathrm{CO}_{2}$ Emissions in Subalpine Forests. Ecology 2005, 86, 419-430. [CrossRef]

54. Bates, D.; Maechler, M.; Bolker, B.; Walker, S. lme4: Linear Mixed-Effects Models Using Eigen and S4. 2013 R Package Version 1.0-5. Available online: http://CRAN.R-project.org/package=lme4 (accessed on 22 October 2019).

55. Bartoń, K. MuMIn: Multi-Model Inference. 2013 R Package Version 1.9.13. Available online: http://CRAN.Rproject.org/package=MuMIn (accessed on 22 October 2019).

56. Russell, L. Emmeans: Estimated Marginal Means, Aka LEAST-Squares Means. 2019 R Package Version 1.4.2. Available online: https://CRAN.R-project.org/package=emmeans (accessed on 22 October 2019).

57. Ellis, S.; Franks, D.W.; Robinson, E.J.H. Ecological consequences of colony structure in dynamic ant nest networks. Ecol. Evol. 2017, 7, 1170-1180. [CrossRef]

58. Savolainen, R.; Vepsäläinen, K. A competition hierarchy among boreal ants: Impact on resource partitioning and community structure. Oikos 1988, 51, 135-155. [CrossRef]

59. Punttila, P.; Haila, Y.; Tukia, H. Ant communities in taiga clearcuts: Habitat effects and species interactions. Ecography 1996, 19, 16-28. [CrossRef]

60. Klimetzek, D. Population studies on hill building wood-ants of the Formica rufa-group. Oecologia 1981, 48, 418-421. [CrossRef] [PubMed]

61. Härkönen, S.K.; Sorvari, J. Species richness of associates of ants in the nests of red wood ant Formica polyctena (Hymenoptera, Formicidae). Insect. Conserv. Divers. 2014, 7, 485-495. [CrossRef]

62. Seidl, R.; Baier, P.; Rammer, W.; Schopf, A.; Lexer, M.J. Modelling tree mortality by bark beetle infestation in Norway spruce forests. Ecol. Model. 2007, 206, 383-399. [CrossRef]

63. Linder, M.; Maroschek, M.; Netherer, S.; Kremer, A.; Barbati, A.; Garcia-Gonzalo, J.; Seidl, R.; Delzon, S.; Corona, P.; Kolström, M.; et al. Climate change impacts, adaptive capacity, and vulnerability of European forest ecosystems. For. Ecol. Manag. 2010, 259, 698-709. [CrossRef]

64. Sorvari, J.; Hakkarainen, H. Forest clearing and sex ratio in forest-dwelling wood ant Formica aquilonia. Naturwissenschaften 2007, 94, 392-395. [CrossRef]

65. Pisarski, B.; Czechowski, W. The course of artificial colonization of red wood ants in the Gorce National Park. Mem. Zool. 1990, 44, 37-46.

66. Sorvari, J.; Huhta, E.; Hakkarainen, H. Survival of transplanted nests of the red wood ant Formica aquilonia (Hymenoptera: Formicidae): The effects of intraspecific competition and forest clear-cutting. Insect. Sci. 2014, 21, 486-492. [CrossRef]

67. Way, J.M.; Khoo, K.C. Role of ants in pest management. Annu. Rev. Entomol. 1992, 37, 479-503. [CrossRef]

68. Cilbircioglu, C.; Ünal, S. Bark beetles and their natural enemies on oriental spruce from the Black Sea region of Turkey. J. Agric. Urban Entomol. 2012, 28, 42-56. [CrossRef]

(C) 2020 by the authors. Licensee MDPI, Basel, Switzerland. This article is an open access article distributed under the terms and conditions of the Creative Commons Attribution (CC BY) license (http://creativecommons.org/licenses/by/4.0/). 